\title{
Návrh na úpravu pracoviště za účelem zvýšení produktivity
}

\author{
Filip Rybnikár ${ }^{1}$, llona Kačerová ${ }^{1}$, Pavel Vránek ${ }^{1}$ \\ 1 Západočeská univerzita v PIzni, Fakulta strojní, Katedra průmyslového inženýrství a \\ managementu \\ Univerzitní 2732/8, 30614 Plzeň, Česká republika \\ rybnikar@kpv.zcu.cz \\ ikacerov@kpv.zcu.cz \\ vranek@kpv.zcu.cz
}

\begin{abstract}
Anotace: Článek se zabývá využitím racionalizačních metod pro návrh na zlepšení současného stavu pracoviště. Návrh nového pracoviště je zaměřen na zvýšení efektivity a produktivity pracoviště za dodržení ergonomických limitů a s ohledem na bezpečnost práce. Návrh spočívá v prvotním odhalení potenciálu pro zlepšení a následné implementaci opatření na pracoviště za docílení vyšší efektivity. Cílem studie bylo vypracovat návrh na úpravu pracoviště za účelem zvýšení jeho efektivity současně s dodržením principů ergonomicky vhodné práce a principů bezpečné práce.
\end{abstract}

\section{1 Úvod}

V současné době je jednou ze základních priorit podniků zlepšovat výrobu s cílem dosažení co nejvyšší efektivity a produktivity. Již dlouhou dobu slouží $\mathrm{k}$ tomuto účelu nástroje a metodiky racionalizace práce a pracoviště. Správným využitím těchto přístupů a implementací metodik Ize dosáhnout efektivního výrobního systému, prípadně dílčích výrobních jednotek.

Zvýšení produktivity Ize dosáhnout také neustálým vyhledáváním, identifikací a odstraňováním plýtvání na pracovišti. Takové plýtvání souvisí především s dlouhými materiálovými toky, dlouhými přechodovými vzdálenostmi pracovníků, nesprávně navrženými dopravními a manipulačními cestami nebo nevhodným uspořádáním z hlediska bezpečnosti a ergonomie práce. Jedním z hlavních cílů podniků je snaha o eliminaci či alespoň redukci každého plýtvání, snižování nákladů na výrobu a docílení vyšší produktivity výroby. [1]

Jedním z možných řešení zvyšování efektivity pracoviště je tvorba vhodného prostorového uspořádání výrobní jednotky. Změnu prostorového uspořádání je nutno podporiit a ověřit dostatkem vstupních dat, návrhu věnovat dostatek času a zajistit správná vstupní data. Př́padné změny již zavedeného návrhu jsou častokrát složité a nákladné. Řešení prostorového uspořádání úzce souvisí s charakterem pracoviště, typem výroby, výrobkovou základnou apod. Těmto faktorům je nutné se důsledně věnovat již při samotném návrhu pracoviště. [2]

Vzhledem k rychlému progresu nejrůznějších podpůrných nástrojů v souvislosti s průmyslem 4.0 jsou návrhy prostorového řešení podpořeny 
softwary a programy umožňujícími nejen klasické 2D layouty, ale také 3D vizualizaci, modely pro nadstavbu pomocí zařízení podporujících virtuální realitu, či vizualizaci a zobrazení hmotných toků produktů nebo produktových rad. [3]

Veškeré návrhy na změny je nutné oprít o dostatek vstupních dat získaných pozorováním a analýzou současného stavu. Součástí analýzy je definice faktorů ovlivňujících produktivitu výroby, kterým je nutné se v dalších fázích věnovat. [1]

Článek je zaměřen na zlepšení výroby zvoleného pracoviště dle přístupů a metodik zlepšování a racionalizace výrobní jednotky. Hlavními činnostmi operátorů $v$ této výrobě je manuální nanášení lepidla na díly pomocí lepící pistole, vyvrtávání a vyřezávání děr, lepení a broušení produktů do konečné podoby. Práce je vykonávána vstoje u pracovního stolu, s občasným přecházením pro potřebný materiál či pro vhodné pracovní nástroje. Model současného stavu pracoviště je na Obrázku 3 - 3D model současného stavu pracoviště.

\section{2 Časová a prostorová analýza}

Na pracovišti bylo pořízeno celkem 5 snímků pracovního dne, který byl měřen $\checkmark$ rámci celých směn ( 8 hod). Tři snímky byly pořízeny na ranní směně $v$ týdenním odstupu, dva snímky na odpolední směně v týdenním odstupu. Výroba probíhá ve dvousměnném provozu. Na základě pozorování pracoviště a pracovníkủ byly definovány hlavní činnosti a operace. Měřené činnosti pracovníka byly zaznamenány do príipraveného dokumentu, který udává spotřebu času jednotlivých činností pracovníků. Dokument byl podroben analýze pro zjištění plýtvání, jeho příčin, potenciálu pro zlepšení a odhalení chyb, kterých se pracovníci dopouštějí včetně ztrát osobních i organizačních.

Snímek pracovního dne dělí jednotlivé činnosti do skupin činností produktivních, podmíněně nutných a ztrátových. Produktivní činnosti jsou přidávající hodnotu, tedy takové, za které zákazník platí, přetváří materiál a jsou provedeny správně na poprvé. Podmíněně nutné činnosti jsou činnosti nepřidávající hodnotu, ale zajištující činnosti produktivní, které je nutné vhodnými úpravami eliminovat či redukovat. Ztrátové činnosti jsou činnosti, které je nutné kompletně odstranit a mohou být způsobeny pracovníkem či organizačními nedostatky. Na Obrázku 1 je znázorněn průměr z měřených snímků pracovního dne zobrazující podíl jednotlivých činností v klasické pracovní směny. 


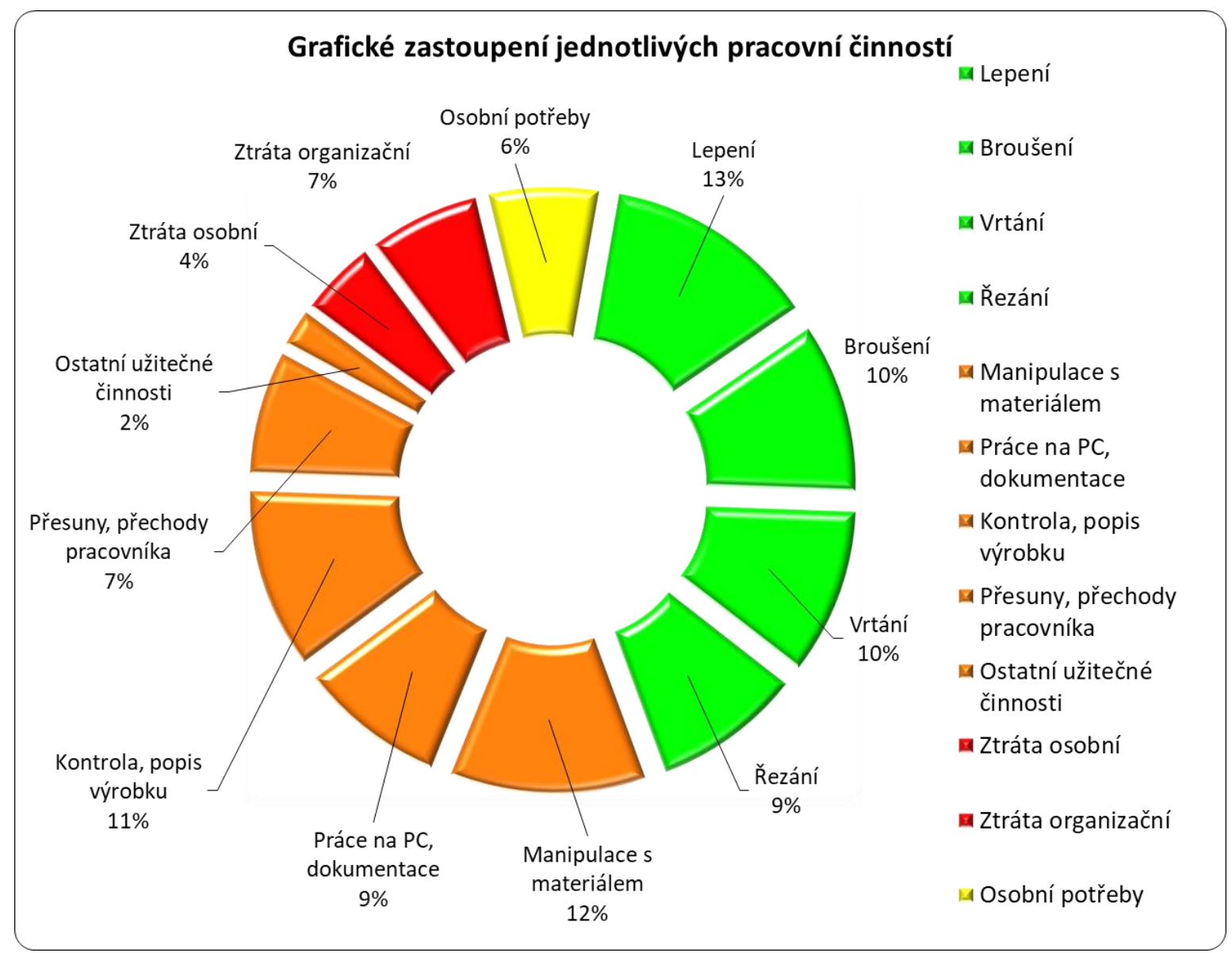

Obrázek 1 - Průměrné procentuální zastoupení činností v rámci pracovní směny

Z grafu je značné, že vysoké procento času bylo spotřebováno na produktivní činnosti spojené s lepením, broušením, vrtáním a řezáním výrobků. $6 \%$ celkového času připadá na osobní potřeby, mezi něž jsou zahrnuty přestávky pracovníků a osobní potřeby (toaleta, občerstvení, svačina). Ztráty organizační, s podílem $7 \%$, zahrnují prostoje nezaviněné pracovníkem (například způsobené chybějícím materiálem). Osobní ztráty představují plýtvání způsobené pracovníkem, kdy pracovník nepracuje, přestože není přestávka (cigareta, osobní rozhovor). Mezi neproduktivní činnosti patří napřiklad přesuny a přechody pracovníka, kontrola hotového kusu, práce s dokumentací nebo manipulace.

Následující graf, viz Obrázek 2, znázorňuje produktivní činnosti zeleně, podmíněně nutné činnosti oranžově, ztrátové činnosti červeně a osobní potřeby pracovníka žlutě. Mezi produktivní činnosti zde byly zařazeny činnosti lepení, broušení, vrtání a řezání. Ztrátové činnosti jsou děleny na ztráty osobní způsobené pracovníkem a ztráty organizační zaviněné nedostatečnou organizací práce. Ostatní činnosti byly zařazeny mezi činnosti podmíněně nutné. 


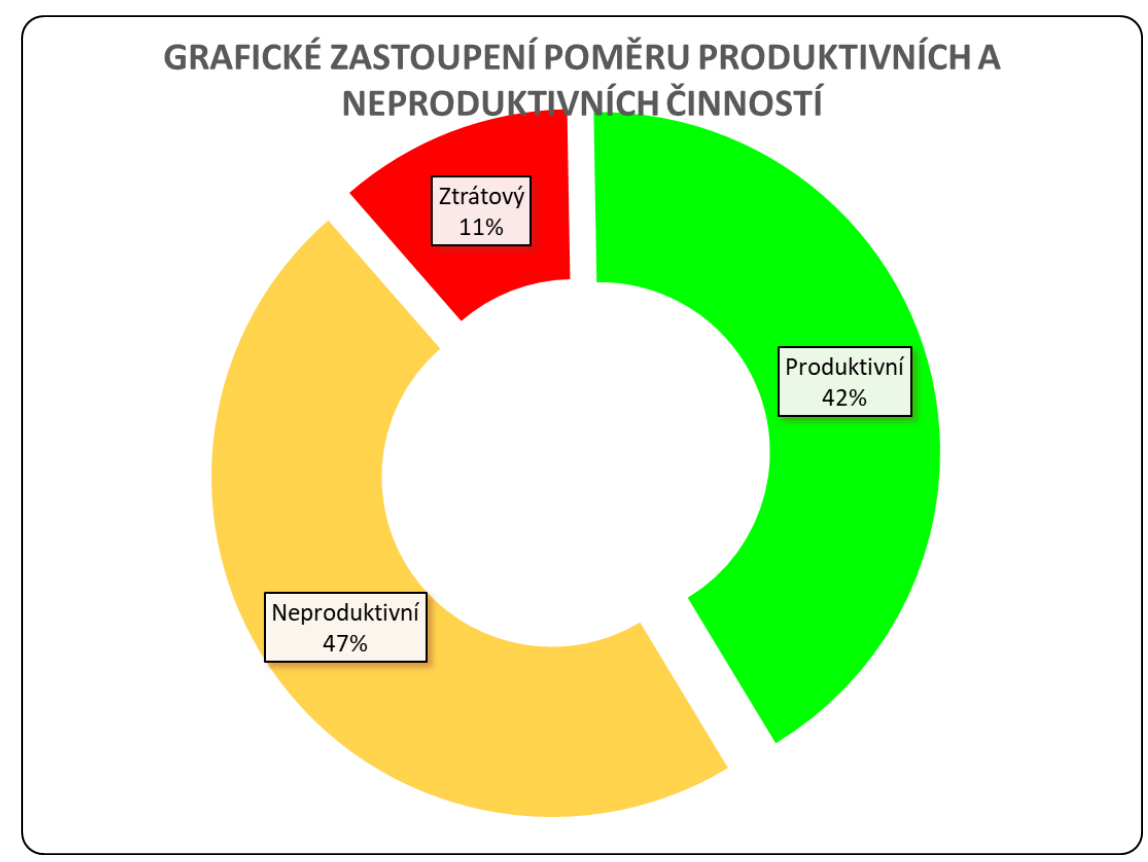

Obrázek 2 - Průměrné procentuální zastoupení skupin činností v rámci směny

Z grafu na Obrázku 2 je patrné, že více než polovina průměrné spotřeby času za pracovní směnu připadá na činnosti neproduktivní a činnosti ztrátové. $\checkmark$ těchto činnostech je nutné dále hledat potenciál pro odstranění plýtvání, zlepšování a tedy zvyšování produktivity. Činnosti ztrátové by dle správného postupu, zodpovědnosti pracovníka a organizace práce měly být kompletně eliminovány. Otázkou jsou činnosti neproduktivní, jež není možné úplně ze spotřeby času směny vyloučit, jelikož slouží pro zajištění činností produktivních. Nicméně $v$ těchto činnostech se častokrát nalézá skryté plýtvání, které představuje potenciál pro zvýšení efektivity, a zavedením vhodných nápravných opatření v podobě racionalizačních prístupů a metodik je možné dosáhnout určitého zlepšení. Následující kapitoly se budou věnovat právě tomuto skrytému plýtvání.

$\mathrm{Na}$ Obrázek 3 je znázorněn 3D model pracoviště vytvořený dle prostorové analýzy současného stavu pracoviště. Vzhledem $\mathrm{k}$ prostorovému řešení jsou zde vidět body $\mathrm{k}$ budoucímu řešení. Umístění stolů a vstupního/výstupního materiálu $v$ současném rozmístění nevyhovuje dostatečné velikosti pracovního prostoru pro pracovníka. Vstupní a výstupní materiál není rozlišen a nachází se na paletě na zemi, přičemž manipulace kusů z palety na pracovní stůl a zpět je prováděna ručně pracovníkem. Skříně na nářadí také nevyhovují požadavkům pracoviště, nástroje jsou v nich nepřehledně uložené a nedostačují svojí kapacitou. 


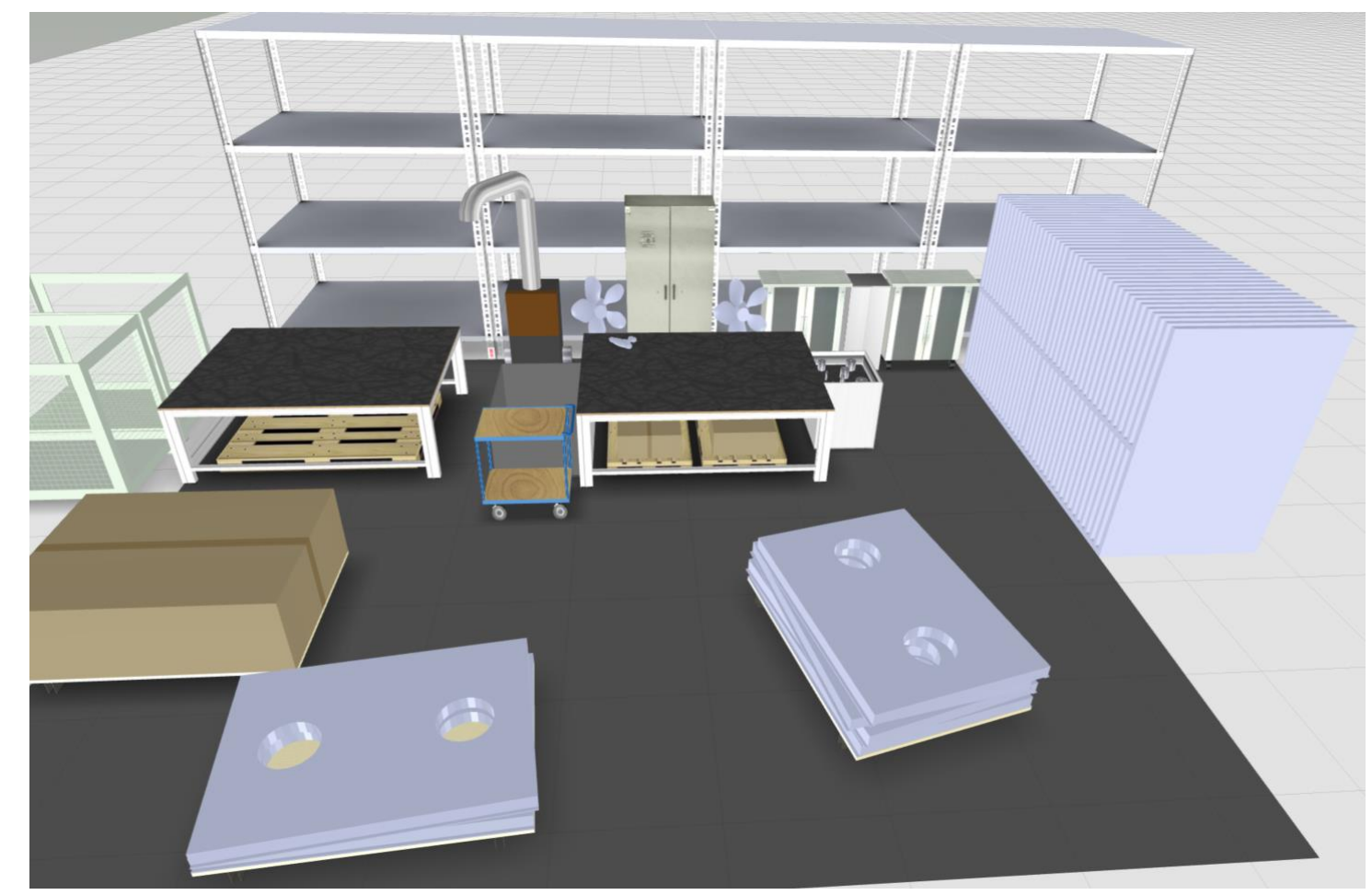

Obrázek 3 - 3D model současného stavu pracoviště

\section{Potenciál pro zlepšení pracoviště}

Při analýze časových snímků došlo k odhalování nedostatků, a tedy i potenciálu postupného zlepšování výrobní jednotky. Zavedením vhodných opatření je možné tuto jednotku zlepšit a dosáhnout vyšší efektivity a produktivity pracoviště. $\vee$ rámci analýz byly odhaleny tyto nedostatky zpưsobující vznik skrytého plýtvání:

- nepřehlednost $v$ uspořádání nástrojů a nářadí,

- dlouhá trasa mezi jednotlivými pracovišti, které pracovník využívá,

- chybí označení vstupního/výstupního materiálu,

- nedostatek prostoru,

- nepořádek ve skříni s nástroji,

- nepořádek na pracovním stole,

- nevyznačená místa pro vozíky,

- vozíky vysoko/nízko,

- špatné ovladatelnost vozíků,

- pomíchané šablony na pracovním stole,

- odkládací prostor vysoko,

- nanášecí pistole a další nářadí na pracovním stole,

- neočištěné kusy,

- nízké/vysoké stoly,

- c čtení dokumentace, hledání ve výkresech.

Jedním ze základních prístupů, který pomůže zlepšování této výrobní jednotky je princip metodiky $5 \mathrm{~S}$. Tato metodika, skládající se z několika 
základních kroků (roztř́dit, uspořádat, čistit, standardizovat, zlepšovat) napomáhá $\mathrm{k}$ udržování čistého, organizovaného a výkonného pracoviště Ize použít na jakémkoliv pracovišti. Cílem metodiky je odstranění přebytečného materiálu, nástrojů, nářadí, šablon a dalšího vybavení pracoviště, které není využíváno. Dalším principem metodiky je zavedení standardu pracoviště pro jeho udržitelnost $v$ čistém a organizovaném stavu. Zároveň by každý předmět na pracovišti měl mít své místo a na tomto místě by měl být kdykoliv nalezen. [4]

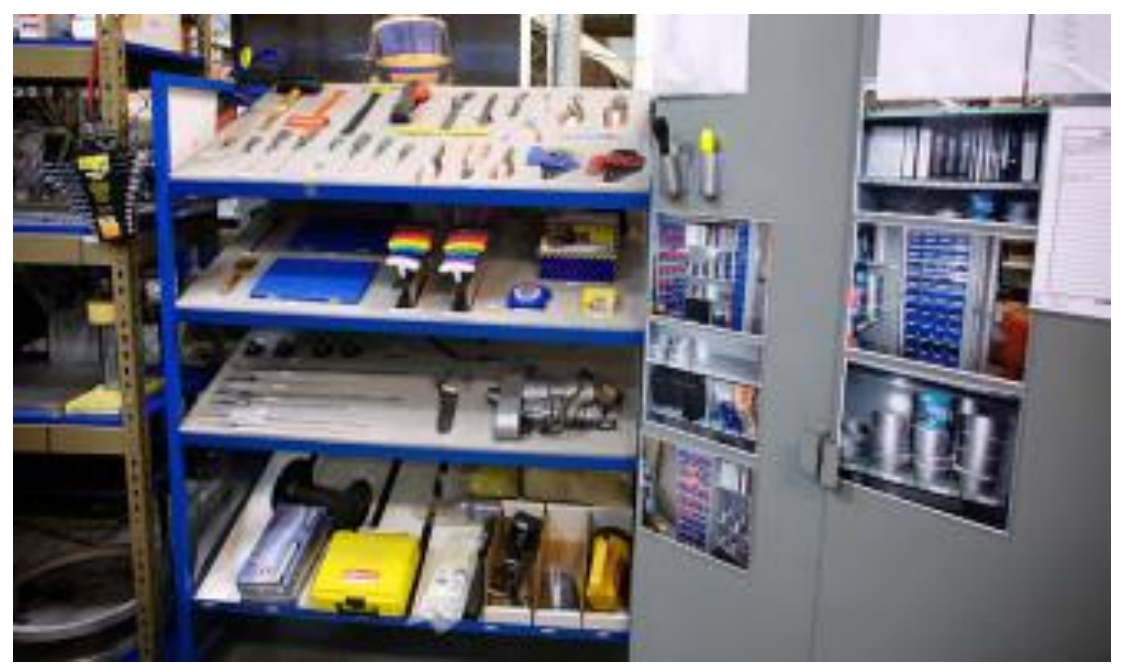

Obrázek 4 - Ukázka uspořádaného pracoviště zavedením metodiky 5S [5]

Pro zamezení nevhodné manipulace materiálu z hlediska ergonomie a bezpečnosti práce by bylo vhodné pořídit na pracoviště ergonomické vozíky pro usnadnění manipulace. Zavedením je docíleno zjednodušení manipulace, tedy k úspoře času potřebného pro manipulaci a zároveň jsou zabezpečeny ergonomicky vhodné podmínky práce pro pracovníka. Zároveň je třeba zohlednit hodnocení pracovních poloh a lokální svalové zátěže dle NV 361/2007 Sb. [6]

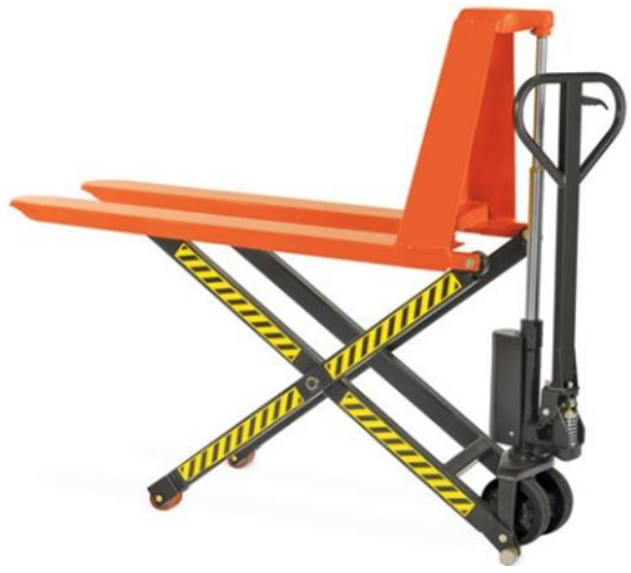

Obrázek 5 - Ukázka nůžkového paletového vozíku [7]

Obdobný problém z hlediska ergonomie skrývají pracovní stoly, které jsou pro některé pracovníky nižšího vzrůstu moc vysoko, a naopak pro pracovníky vyššího vzrůstu moc nízko. Proto je vhodné zavést na pracoviště ergonomické vhodné výškově nastavitelné pracovní stoly. 


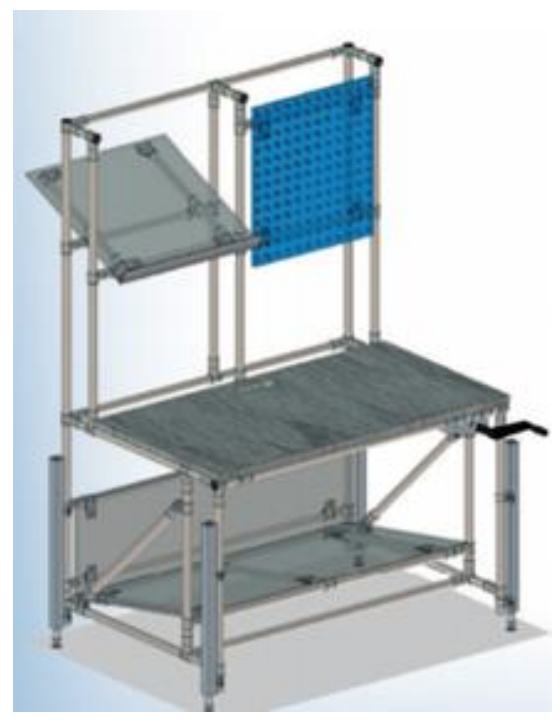

Obrázek 6 - Ukázka výškově nastavitelného pracovního stolu [8]

Nepořádek $v$ podobě neuspořádaného a nepřehledně uloženého nářadí a nástrojů, případně nepořádek ve skříni s nástroji a na pracovním stole, je také nutné řešit vzhledem ke zvýšení efektivity pracoviště. Tento nedostatek Ize rešit pomocí vhodných úložných prostor s definovanými prostory pro nástroje a nářadí. Pro zamezení problému s nepřehledným uložením šablon je nutné vytvořit vhodné prostory např́klad pomocí regálu pro tyto šablony. Některé nástroje volně leží na pracovním stole pracovníka, přestože s nimi v daný moment nepracuje. Jednoduchým zavedením držáků pod pracovní desku stolu je možné tomuto problému zabránit.

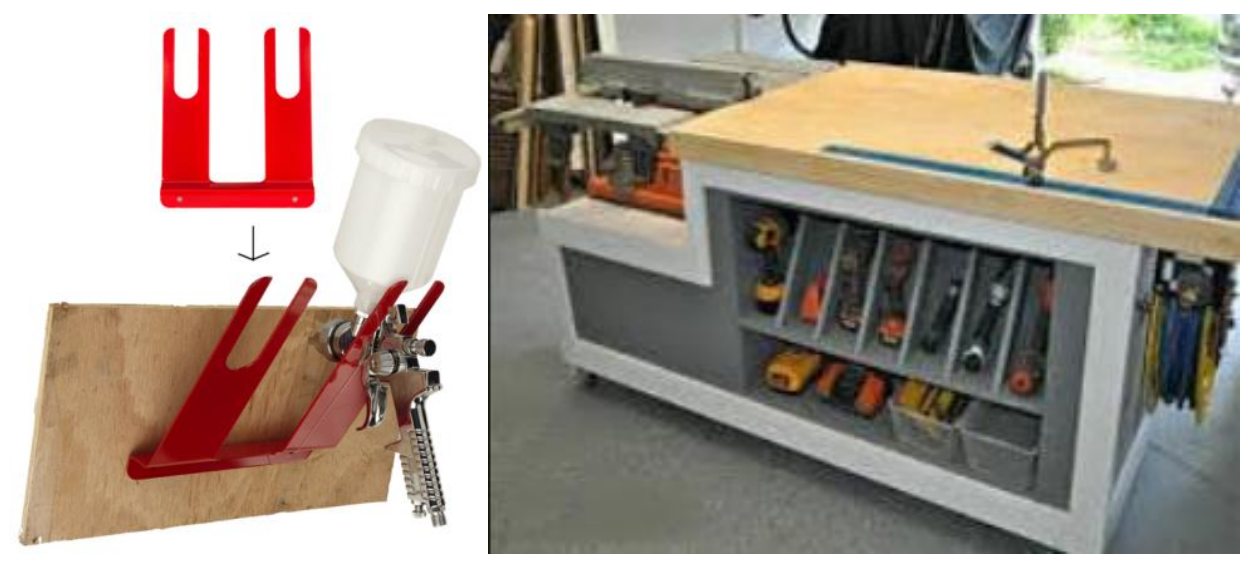

Obrázek 7 - Ukázka možných úložných prostor pro pracovní nástroje a nářadí [9]

Pro uložení materiálu do úložných prostor je možné využít řešení pomocí karuselových skříní, které jsou schopné pojmout velké množství uloženého vybavení pracoviště s definovaným místem pro každé $z$ nich. 


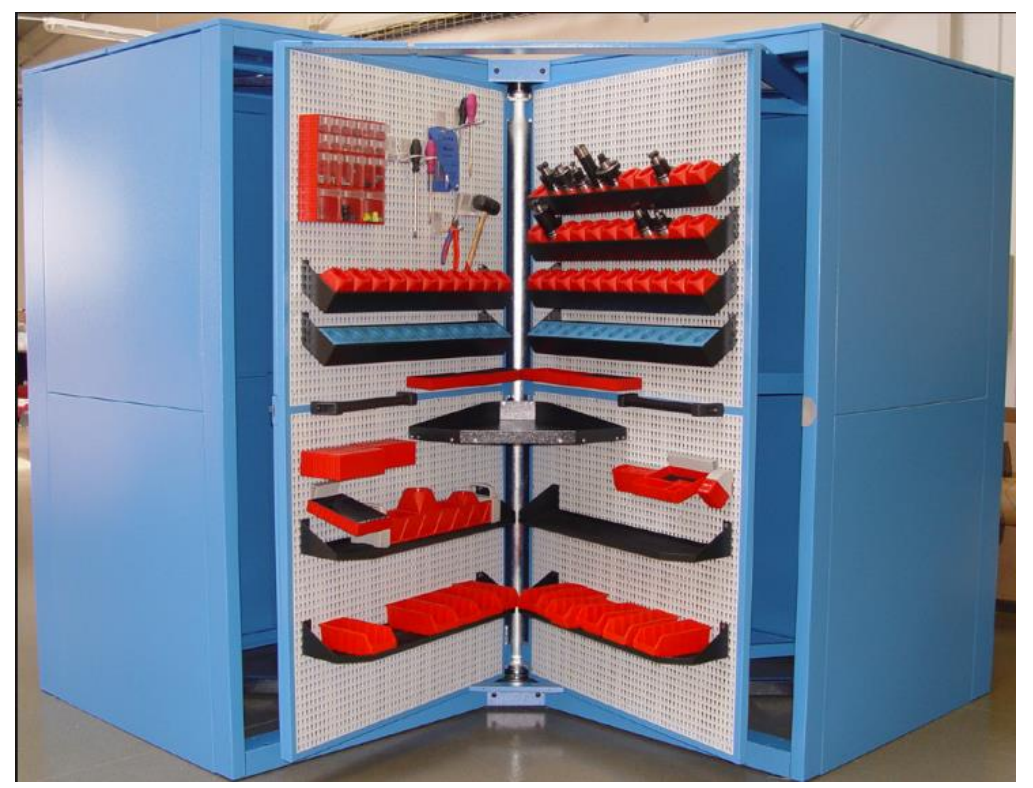

Obrázek 8 - Ukázka karuselové skříně pro uložení vybavení [10]

Velkým nedostatkem v náplni práce pracovníka je dlouhé čtení výkresové dokumentace, kdy pracovník zjišt'uje, jakým způsobem provést výrobu příslušného výrobku. Tímto hledáním v dokumentaci pracovník tráví dle snímku pracovního dne přibližně $10 \%$ času z pracovní směny. Zavedením vhodné náhrady papírové a výkresové dokumentace je možnost docílit nižšího procenta spotřeby času na tuto činnost. Možnou alternativou je čtení výkresové dokumentace či návodu na výrobu z monitoru umístěného na pracovišti. Dokumentace je načtena pomocí skeneru a příslušného kódu a online promítnuta do PC. Takto má pracovník vše v zorném poli, dokumentace je větší a lépe čitelná. Další alternativou je využití dotykové obrazovky.

\section{$4 \quad$ Návrh a model pracoviště}

Návrh nového prostorového uspořádání výrobní jednotky byl vytvořen s ohledem na ergonomii a bezpečnost práce. Zároveň byly aplikovány návrhy opatření, které redukují skryté plýtvání způsobené nedostatky vypozorované během snímkování a následných analýzách.

Na Obrázek 9 je znázorněn nový návrh prostorového uspořádání pracoviště. Návrh se opírá o vypozorované nedostatky a potenciál pro zlepšení efektivity a produktivity výrobní jednotky. Vzhledem k prostorovému uspořádání byl vytvořen větší pracovní prostor okolo pracovních stolů přiražením stolů k sobě, čímž byl zároveň prodloužen pracovní prostor. Stoly jsou natočené o $90^{\circ}$ z důvodu lepšího prístupu vstupního a výstupního materiálu. Pracovní stoly byly značně inovovány, obsahuji kuličky, které pomáhají pracovníkovi s manipulací větší a těžších kusů. Stoly jsou výškově nastavitelné a jsou položeny na zajištěných kolečkách pro případný přesun. Držáky na nástroje a nářadí potřebného na tomto pracovišti (nanášecí pistole, vrtačky, řezačky, brusky) jsou vzhledem k respektování ergonomických pravidel (nezvedání 
ramene nad $60^{\circ}$ apod.) umístěny pod pracovní deskou stolu, pracovník se $\mathrm{k}$ tomuto nářadí nemusí ohýbat, vše je umístěno v komfortní dosahové zóně. $\mathrm{Na}$ pracoviště byla umístěna rohová karuselová skřiňn, kde je možné uchovávat veškeré nástroje, šablony, vrtáky apod. Vedle karuselové skříně se nachází i skřriňka na uložení osobních věcí - jídlo, pití atd. Pracovník má na pracovišti $k$ dispozici PC s monitorem zobrazující výkresovou dokumentaci výrobku, opatřený čtečkou pro načtení dokumentace a promítání výkresů. Pro usnadnění manipulace materiálu je pracoviště opatřeno nůžkovými paletovými vozíky.

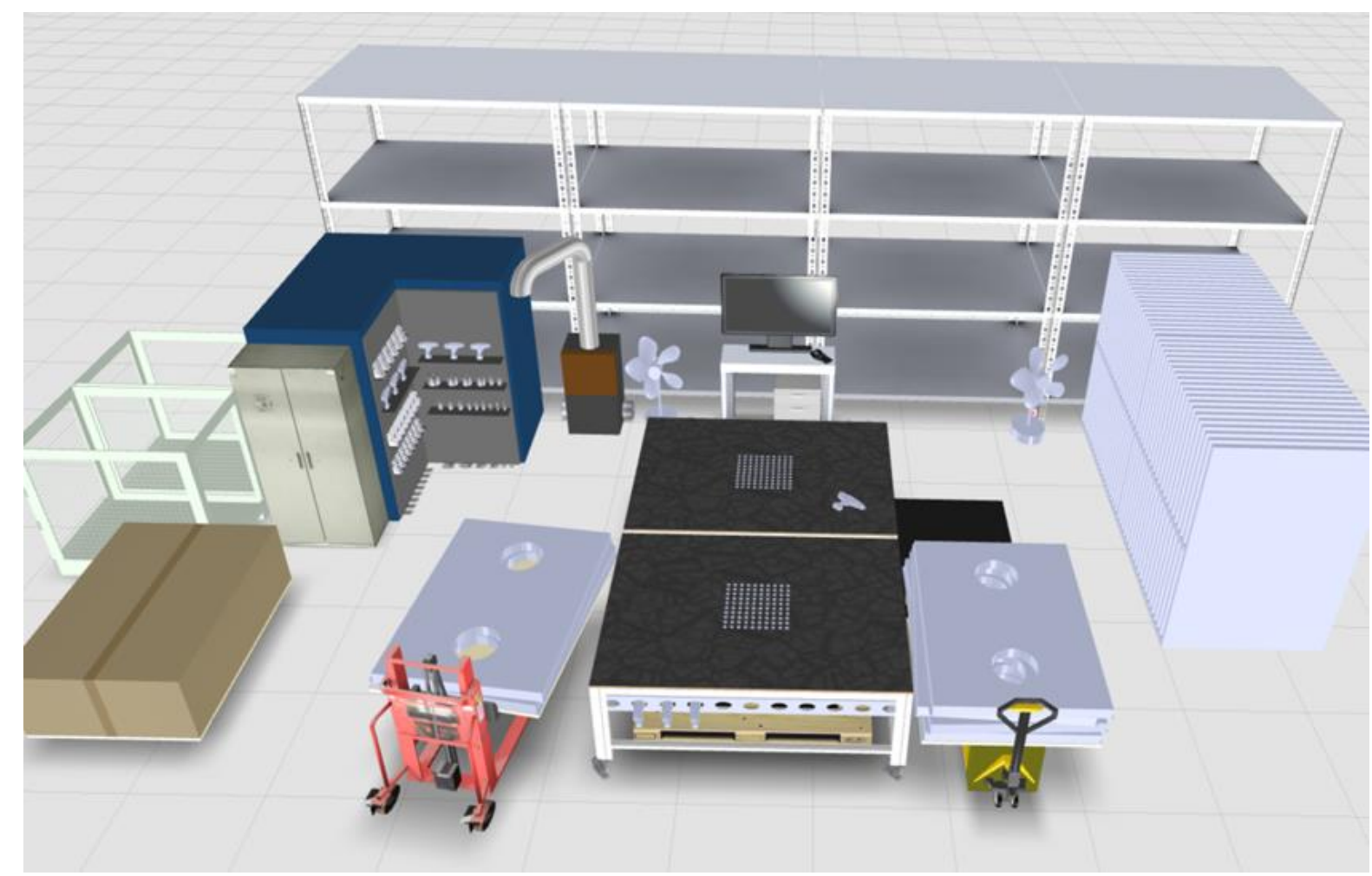

Obrázek 9 - Návrh nového prostorového usporádáni pracoviště

Pro udržení organizovaného pracoviště je vhodné využít implementace metodiky 5 S po reorganizaci pracoviště a uvedení do provozu.

\section{Závěr}

Racionalizace pracoviště patři mezi důležité metody průmyslového inženýrství. Přístupů $k$ řešení racionalizace pracoviště je mnoho, přičemž prínosy z provedení jsou vždy pro společnost značnou výhodou. Jednou z možností racionalizace pracoviště je pochopení fungování a mapování činností pracoviště, provedení časových a prostorových analýz, následně stanovení nedostatků a potenciálů pro zlepšení a v závěru tyto změny provést a následně dlouhodoběji udržovat. Takový přístup byl využit $v$ rámci této studie, kdy došlo $\mathrm{k}$ vytvoření návrhu nového prostorového uspořádání pracoviště reflektujícího navrhované změny s ohledem na eliminaci plýtvání. Návrh byl vytvořen se zřetelem na ergonomii pracoviště a bezpečnost práce. 


\section{Poděkování}

Tento článek byl vytvořen za podpory interního grantu Západočeské univerzity číslo projektu je SGS-2018-031 s názvem Optimalizace parametrů udržitelného výrobního systému.

\section{Použitá literatura}

[1] KOŠTURIAK, J. Projektovanie výrobných systémov pre 21. storočie. Žilina: EDIS, 2000. ISBN 80-7100-553-3.

[2] BUREŠ, M. Tvorba a optimalizace pracoviště. 1. vyd. Plzeň: SmartMotion s.r.o., 2013. ISBN 978-80-87539-32-3.

[3] VRÁNEK, P., ŠIMON, M. Návrh a optimalizace prostorového uspořádání výrobního úseku. Průmyslové inženýrství, 2018. s. 126-133.

[4] ŠIMON, M. Průmyslové inženýrství. e-book, ZČU-KPV PIzeň, 2015.

[5] Ütana. In: uttana.com [online]. [cit. 8.8.2020]. Dostupné z: https://uttana.com/shop/5ss-of-the-5s-methodology/

[6] KAČEROVÁ, I., BUREŠ, M. Ergonomická optimalizace pracoviště. Průmyslové inženýrství, 2018. s. 30-38.

[7] Profi Shop. In: jungheinrich-profishop.cz [online]. [cit. 8.8.2020]. Dostupné z: https://www.jungheinrich-profishop.cz/nuzkove-paletove-voziky/

[8] Profi Regály. In: profiregaly.cz [online]. [cit. 8.8.2020]. Dostupné z: https://www.profiregaly.cz/nerezove-stojany-stacionarni/7968-nerezovystojan-stacionarni-d1200-mm-8595664930173.html

[9] Aj Produkty. In: ajprodukty.cz [online]. [cit. 8.8.2020]. Dostupné z: www.ajprodukty.cz/sklady-dilny-a-prumysl/dilensky-nabytek-avybaveni/pracovni-stoly/

[10] Hofmeister Carousel. In: http://www.carousel.cz/ [online]. [cit. 8.8.8.2020]. Dostupné z: http://www.carousel.cz/pdf/CAROUSEL.pdf 